Buletin Ilmiah Mat. Stat. dan Terapannya (Bimaster)

Volume 08, No. 4 (2019), Hal 789-798.

\title{
PENENTUAN GARIS KEMISKINAN PROVINSI MENGGUNAKAN METODE MULTIPLE CLASSIFICATION ANALYSIS
}

\author{
Alvin Firdaus, Shantika Martha, Nurfitri Imro'ah
}

\begin{abstract}
INTISARI
Multiple classification analysis (MCA) adalah metode yang dapat digunakan untuk menganalisis hubungan beberapa variabel bebas yang berskala kategorik (nominal atau ordinal) dengan sebuah variabel terikat yang berskala numerik (interval atau rasio). Metode MCA memberikan hasil yang memuaskan dalam mengidentifikasi hubungan antara variabel bebas dan terikat, dimana MCA dapat menghasilkan parameter untuk seluruh kategori, dan juga dapat mengukur besarnya hubungan variabel dependen dengan masing-masing variabel bebas sebelum dan setelah dikontrol variabel bebas lain melalui statistik eta dan statistik beta. Tujuan dari penelitian ini adalah untuk menentukan model MCA pada faktor-faktor yang berpengaruh terhadap garis kemiskinan provinsi (GKP). Data yang digunakan pada penelitian ini adalah data publikasi BPS tahun 2017 yang meliputi data rata-rata lama sekolah $(R L S)$, product domestic regional bruto (PDRB), pengeluaran perkapita perbulan (PPP), upah minimum provinsi (UMP), tingkat pengangguran terbuka (TPT) dan inflasi (I) pada 34 provinsi di Indonesia. Hasil analisis menunjukkan bahwa RLS, PDRB dan PPP berpengaruh signifikan terhadap GKP. PPP merupakan faktor yang paling berpengaruh terhadap GKP yaitu dengan nilai eta sebesar $71,9 \%$ dan beta sebesar 58,1\%. Sedangkan variabel PDRB memiliki nilai eta sebesar $65,7 \%$ dan nilai beta $39,9 \%$. Variabel RLS hanya memiliki nilai eta 47,2\% dan beta sebesar 14,0\%. Model MCA yang diperoleh juga memberikan hasil yang sangat baik karena memiliki nilai MAPE 8,93\%.
\end{abstract}

Kata Kunci: MCA, Statistik Eta, Statistik Beta

\section{PENDAHULUAN}

Kemiskinan merupakan masalah yang sangat krusial bagi setiap negara di dunia. Kemiskinan dianggap memiliki dampak negatif terhadap multi sektoral, tidak hanya pada kondisi sosial ekonomi, akan tetapi juga meliputi masalah pendidikan, kesehatan dan instabilitas politik sebuah negara. Dunia internasional dalam hal ini PBB bersepakat menjadikan topik pengentasan kemiskinan sebagai satu dari 17 tujuan pembangunan berkelanjutan bagi kemaslahatan manusia. Ke-17 tujuan tersebut termuat di dalam dokumen sustainable development goals (SDGs), dimana penghapusan kemiskinan merupakan tujuan nomor satu yang berbunyi "no poverty" atau tidak ada kemiskinan dalam bentuk apapun di seluruh penjuru dunia.

Pada umumnya setiap negara memiliki indikator untuk mengukur kemiskinan negaranya masingmasing. Indikator kemiskinan menurut world bank adalah penduduk yang hidup dibawah garis kemiskinan internasional yaitu mereka yang konsumsi perharinya atau pendapatannya kurang dari \$2 perhari. Untuk mengukur garis kemiskinan, Indonesia menggunakan konsep kemampuan memenuhi kebutuhan dasar. Dengan pendekatan ini, kemiskinan dipandang sebagai ketidakmampuan dari sisi ekonomi untuk memenuhi kebutuhan dasar makanan dan bukan makanan yang diukur dari sisi pengeluaran. Garis kemiskinan diperoleh dari penjumlahan garis kemiskinan makanan dan garis kemiskinan nonmakanan. Garis kemiskinan dipergunakan sebagai suatu batas untuk mengelompokkan penduduk menjadi miskin atau tidak miskin. Penduduk miskin adalah penduduk yang memiliki ratarata pengeluaran per kapita per bulan di bawah garis kemiskinan [1]. Selain itu, garis kemiskinan juga bersifat unik untuk setiap daerah provinsi. Hal ini dikarenakan kemiskinan pada suatu provinsi dipengaruhi oleh faktor dari dalam provinsi itu sendiri, seperti tingkat pertumbuhan ekonomi, sosial dan pendidikan di provinsi tersebut [2]. Oleh karena itu dalam penelitian ini, akan dianalisis faktorfaktor yang berpengaruh dalam penentuan garis kemiskinan provinsi (GKP) di Indonesia menggunakan metode multiple classification analysis (MCA).

MCA merupakan metode analisis inferensia yang menggunakan uji statistik dan hampir mirip dengan analisis regresi dengan variabel dummy, dimana variabel bebasnya berskala ukuran kategorik. Pada analisis regresi dengan variabel dummy, kategori yang menjadi acuan harus dikeluarkan dari 
analisis ketika menyusun persamaan model regresinya. Dengan demikian, bagi kategori yang menjadi acuan tidak akan diperoleh nilai koefisien regresinya, padahal koefisien-koefisien regresi lainnya dinyatakan sebagai perbandingan dari kategori yang menjadi acuan. Akan tetapi, MCA memiliki kelebihan dibandingkan dengan analisis regresi dengan variabel dummy. Koefisien regresi MCA dihitung untuk seluruh kategori pada setiap variabel bebasnya [3].

Analisis data diawali dengan membuat kategori-kategori variabel bebas. Kemudian melakukan uji normalitas data, uji ini dilakukan sebagai asumsi yang harus dipenuhi dalam uji anova pada tahap selanjutnya. Kemudian melakukan uji anova untuk menguji keterkaitan antara variabel bebas dan variabel terikat. Berdasarkan uji anova akan dipilih variabel yang memiliki keterkaitan dengan variabel terikat. Variabel bebas yang tidak memiliki hubungan, maka tidak akan diikutsertakan dalam analisis MCA. Setelah dilakukan uji anova, langkah selanjutnya yaitu melakukan analisis MCA yang akan menghasilkan parameter-parameter bagi kategori-kategori yang termuat dalam setiap variabel bebas. Selanjutnya mengukur besarnya pengaruh variabel bebas dalam model terhadap variabel GKP melalui statistik eta dan beta. Setelah diperoleh model GKP, selanjutnya adalah mengestimasi nilai GKP dari 34 provinsi di Indonesia dengan metode MCA. Kemudian untuk melihat seberapa akurat model GKP yang dihasilkan, maka dihitung mean absolute percentage error (MAPE).

\section{DISTRIBUSI FREKUENSI}

Distribusi frekuensi dapat digunakan sebagai langkah awal dalam analisa data. Distribusi frekuensi merupakan tabel, dimana data dikelompokan kedalam beberapa interval numerik yang disebut sebagai interval kelas. Bentuk tabel distribusi sangat sederhana, karena hanya menyajikan jumlah pengamatan atau frekuensi dari setiap interval kelas.

Berikut ini beberapa yang harus diperhatikan dalam membuat tabel distribusi frekuensi [4]

1. Penentuan jumlah interval kelas

Jumlah interval kelas yang digunakan sangat tergantung pada jumlah pengamatan dalam data.

Semakin besar jumlah datanya maka akan semakin banyak jumlah kelas yang diperlukan.

2. Penentuan interval kelas

Interval kelas dalam tabel distribusi frekuensi dianjurkan agar mempunyai lebar interval yang sama. Penentuan lebar interval dilakukan dengan menentukan lebih dulu kisaran datanya, yaitu selisih antara nilai data terbesar dengan data terkecil, kemudian membaginya dengan jumlah interval yang diinginkan:

3. Penentuan batas interval kelas

Batas antar interval kelas harus ditentukan dengan jelas dan tidak bertumpang tindih sehingga nilai-nilai pengamatan dapat dengan tepat dikelompokkan ke dalam setiap kelas. Batas bawah interval kelas yang pertama biasanya adalah nilai minimum dari data tersebut, atau nilai yang sedikit lebih kecil dari nilai minimum tersebut. Sedangkan batas atas interval kelas yang terakhir ditentukan sedemikian rupa sehingga nilai maksimum dari data tersebut terletak pada interval kelas yang terakhir

\section{PERSENTIL DATA}

Nilai persentil ke- $p$ dari suatu set data yang telah diurutkan besarannya adalah suatu nilai yang membagi dua urutan data tersebut sedemikian rupa sehingga sebanyak $p \%$ dari data terletak dibawah nilai tersebut dan $(100-p) \%$ nya terletak di atas nilai tersebut [4]. Nilai persentil yang sering digunakan adalah persentil ke-25, ke-50, dan ke-75, yang masing-masing biasa disebut sebagai kuartil bawah, kuartil tengah(median) dan kuartil atas. Untuk menentukan nilai-nilai kuartil tersebut, pertamatama urutkan nilai-nilai data menurut besarnya, misalnya dari nilai terkecil ke nilai terbesar. Kuartil bawah $(Q 1)$ adalah nilai pengamatan yang terletak pada urutan ke $\frac{n+1}{4}$; kuartil tengah (median) adalah nilai pengamatan yang ke $\frac{n+1}{2}$; dan kuartil atas $(Q 3)$ adalah nilai pengamatan yang ke $\frac{3(n+1)}{4}$ dalam urutan tersebut.

\section{UJI NORMALITAS KOLMOGOROV-SMIRNOV}

Misalkan $x_{1}, x_{2}, \ldots, x_{n}$ adalah sampel random berukuran $n$ dari suatu populasi dengan fungsi distribusi $F(x)$. Andaikan $F_{0}(x)$ adalah fungsi teoritik atau suatu fungsi distribusi tertentu dan akan diuji [5]: 


$$
\begin{array}{ll}
\mathrm{H}_{0}: F(x)=F_{0}(x) \text { untuk semua } x & \text { (data berdistribusi tertentu) } \\
\mathrm{H}_{1}: F(x) \neq F_{0}(x) \text { untuk suatu } x & \text { (data tidak berdistribusitertentu) }
\end{array}
$$

Uji Kolmogorov-Smirnov dilakukan dengan menggunakan statistik uji:

$$
D=\max _{-\infty<x<\infty}\left|F_{n}(x)-F_{0}(x)\right|
$$

dengan $F_{n}(x)$ adalah fungsi distribusi empirik berdasarkan sampel random $x_{1}, x_{2} \ldots x_{n} . \mathrm{H}_{0}$ ditolak jika nilai $D>D_{n, \alpha}$, dengan $D_{n, \alpha}$ merupakan nilai kritik dari tabel Kolmogorov-Smirnov.

\section{UJI ANOVA}

Anova merupakan analysis statistik untuk menguji perbedaan rata-rata lebih dari 2 populasi. Terdapat dua jenis anova yaitu anova satu jalur dan anova dua jalur. Pada penelitian ini digunakan proses uji anova satu jalur. Pengujian anova satu jalur secara umum dilakukan dengan ketentuan sebagai berikut [6].

Dengan hipotesis:

$$
H_{0}: \mu_{1}=\mu_{2}=\cdots=\mu_{k}
$$

$H_{1}$ : minimal ada satu $\mu_{i} \neq 0$, dengan $i=1,2, \ldots, k$

Statistik uji yang digunakan adalah uji $F$ dengan derajat bebas pembilang $=k-1$ dan derajat bebas penyebut $=N-k$. Dimana $k$ merupakan banyak populasi $/$ kategori pada variabel dan $N$ adalah banyaknya data. Perhitungan F hitung sebagai berikut.

$$
F=\frac{\sum_{i}^{k} n_{i}\left(\overline{\mathrm{x}}_{i}-\bar{x}\right) /(k-1)}{\sum_{i}^{k} \sum_{j}^{N}\left(\mathrm{x}_{i j}-\bar{x}_{i}\right) /(N-k)}
$$

Selanjutnya keputusan diambil berdasarkan kriteria bahwa $H_{0}$ ditolak jika nilai $F>F_{((\mathrm{k}-1),(\mathrm{N}-k))}$.

\section{MAPE (MEAN ABSOLUTE PERCENTAGE ERROR)}

Pada saat mengestimasi suatu nilai, pasti akan mengandung derajat ketidakpastian. Fakta ini didapatkan dengan memasukkan unsur kesalahan (galat). Dalam usaha untuk mendapatkan model yang tepat atau menghasilkan estimasi yang mendekati nilai aslinya, maka digunakan tingkat kesalahan sekecil mungkin. Pada penelitian ini, MAPE digunakan untuk mengukur tingkat kesalahan pada model GKP yang akan diestimasi.

$$
M A P E=\frac{1}{N} \sum_{i=1}^{N}\left|\frac{Y_{i}-\hat{Y}_{i}}{Y_{i}}\right| \times 100 \%
$$

Dimana :

$Y_{i}=$ Nilai sebenarnya pada pengamatan ke- $i$

$\hat{Y}_{i}=$ Nilai estimasi pada pengamatan ke- $i$

$N=$ Banyaknya data

Jika MAPE kurang dari $10 \%$ maka kemampuan sebuah model mengestimasi atau meramal dinilai sangat baik, dan jika nilai MAPE pada rentang antara $10 \%$ sampai $20 \%$ maka model disebut memiliki kemampuan estimasi yang baik[7].

\section{MULTIPLE CLASSIFICATION ANALYSIS (MCA)}

Model MCA hampir mirip dengan model regresi dengan variabel dummy. Perbedaannya adalah model regresi dummy hanya memberikan parameter regresi untuk kategori acuan saja, sedangkan pada model MCA dapat ditentukan untuk setiap kategori dari setiap variabel bebas. Pada model ini, nilai 
variabel terikat didefinisikan sebagai penjumlahan setiap parameter dari kategori, ditambah rata-rata keseluruhan (grand mean) dan ditambah dengan residual [3].

$$
Y_{i j . . . n}=\bar{Y}+a_{i}+b_{j}+c_{k} \ldots+\varepsilon_{i j \ldots . . n}
$$

Keterangan:

$Y_{i j \ldots n}=$ Nilai variabel terikat yang berada pada kategori ke- $i$ variabel $A$, kategori ke- $j$ variabel $B$, kategori ke- $k$ variabel $C$ dan seterusnya

$\bar{Y} \quad=$ Rata-rata keseluruhan (grand mean)

$a_{i} \quad=$ Parameter kategori ke- $i$ pada variabel $A$

$b_{\mathrm{j}} \quad=$ Parameter kategori ke-j pada variabel $B$

$\varepsilon_{i j \ldots n}=$ Residual untuk individu yang bersesuaian dengan $Y_{i j \ldots . . n}$

Simbol $a_{i}, b_{j}, c_{k}$, adalah nilai estimasi parameter model dari kategori tiap variabel yang ditentukan menggunakan metode kuadrat terkecil melalui persamaan normal. Bentuk persamaan normal tersebut adalah:

$$
\begin{aligned}
& a_{i}=A_{i}-\bar{Y}-\frac{1}{w_{i}} \sum_{j} w_{i j} b_{j}-\frac{1}{w_{i}} \sum_{k} w_{i k} c_{k} \\
& b_{j}=B_{j}-\bar{Y}-\frac{1}{w_{j}} \sum_{i} w_{j i} a_{i}-\frac{1}{w_{j}} \sum_{k} w_{j k} c_{k} \\
& c_{k}=C_{k}-\bar{Y}-\frac{1}{w_{k}} \sum_{i} w_{k i} a_{i}-\frac{1}{w_{k}} \sum_{j} w_{k j} b_{j}
\end{aligned}
$$

Keterangan:

$A_{i}=$ nilai rata-rata variabel terikat pada kategori ke- $i$ variabel $A$,

$B_{j}=$ nilai rata-rata variabel terikat pada kategori ke- $j$ variabel $B$,

$C_{k}=$ nilai rata-rata variabel terikat pada kategori ke- $k$ variabel $C$

$w_{i}=$ banyaknya kejadian pada kategori ke- $i$ variabel $A$

$w_{j}=$ banyaknya kejadian pada kategori ke-j variabel $B$

$w_{k}=$ banyaknya kejadian pada kategori ke- $k$ variabel $C$

Sedangkan untuk $w_{i j}$ menunjukkan banyaknya kejadian kategori ke- $i$ variabel $A$ dan kategori ke- $j$ variabel $B$, begitu juga $w_{i k}$ menunjukkan banyaknya kejadian kategori ke- $i$ variabel A dan kategori ke$k$ variabel $C$ dan seterusnya.

Langkah selanjutnya adalah menguji apakah model MCA yang dihasilkan secara umum dapat digunakan untuk mengestimasi variabel terikat. Uji yang dilakukan adalah uji simultan $F$. Dengan hipotesis :

$H_{0}: a_{i}=b_{j}=c_{k}$ (tidak ada perbedaan parameter kategori antar variabel)

$H_{1}: a_{i}, b_{j}, c_{k} \neq 0$ (minimal ada satu parameter kategori tidak sama dengan nol)

Signifikansi dari variabel terikat yang dijelaskan oleh variabel bebas dalam model diuji oleh statistik sebagai berikut [3]

$$
F=\frac{E /(C-P)}{Z /(N-C+P-1)}
$$

Dengan $(C-P)$ dan $(N-C+P-1)$ adalah derajat bebas, $N$ merupakan ukuran sampel, $C$ banyaknya kategori, $P$ banyaknya variabel bebas dan nilai $E$ diperoleh dengan rumus sebagai berikut:

$$
E=\sum_{i}\left(\hat{Y}_{i}-\bar{Y}\right)^{2}
$$

Sedangkan nilai $Z=T-E$ dimana nilai T diperoleh pada Persamaan (8) berikut.

$$
T=\sum_{i}\left(Y_{i}\right)^{2}-\frac{\left(\sum_{i} Y_{i}\right)^{2}}{N}
$$


Dengan $Y_{i}$ adalah nilai variabel terikat sebenarnya, $\hat{Y}_{i}$ adalah nilai estimasi variabel terikat pada pengamatan ke- $i$, dan $\bar{Y}$ adalah grand mean.

Pengambian keputusan Tolak $H_{0}$, Apabila $F>F_{(\mathrm{C}-P),(N-C+P-1)}$ atau $P$-value $<\alpha$ (tingkat kesalahan).

Keputusan tolak $H_{0}$ menunjukkan bahwa model MCA signifikan secara statistik atau dengan kata lain model yang dihasilkan dapat digunakan untuk mengestimasi variabel terikat..

\section{STATISTIK ETA $\left(\boldsymbol{\eta}_{i}\right)$ DAN BETA $\left(\boldsymbol{\beta}_{i}\right)$}

a. Statistik Eta $\left(\eta_{i}\right)$

Eta statistik digunakan untuk mengukur besarnya pengaruh dari variabel bebas ke-i terhadap variabel terikat. Eta mengukur besarnya hubungan sebelum adjusment atau sebelum dikontrol oleh variabel lain. Kadangkala Eta juga dapat disebut sebagai rasio korelasi. Statistik Eta didefinisikan dalam formula sebagai berikut [8]

$$
\eta_{i}=\sqrt{\frac{U_{i}}{T}}
$$

Dimana,

$$
U_{i}=\sum_{j}\left(\bar{Y}_{i j}-\bar{Y}\right)^{2}
$$

$\bar{Y}_{i j}$ adalah mean variabel terikat untuk kategori ke-j variabel ke-i, dan nilai $\mathrm{T}$ diperoleh dengan Persamaan (8)

b. Statisik Beta $\left(\beta_{i}\right)$

Selain statistik eta, ada pula statistik beta yang digunakan untuk mengukur besarnya pengaruh dari variabel bebas ke- $i$ terhadap variabel terikat setelah dikontrol oleh variabel lain. Beta pada variabel ke$i$ dihitung dengan rumus pada Persamaan (11).

$$
\beta_{i}=\sqrt{\frac{D_{i}}{T}}
$$

Dimana,

$$
D_{i}=\sum_{j}\left(w_{i j}\right)\left(a_{i j}\right)^{2}
$$

Dengan $a_{i j}$ adalah adjusted deviasi pada kategori ke- $j$ variabel ke- $i$ dan $w_{i j}$ adalah banyaknya kejadian pada kategori ke-j variabel ke- $i$

\section{KOEFISIEN DETERMINASI MODEL MCA}

Koefisien determinasi didefinisikan sebagi proporsi penurunan keragaman jumlah yang diakibatkan oleh digunakannya variabel bebas. Semakin besar nilai koefisien determinasi semakin besar penurunan keragaman variabel terikat yang diakibatkan oleh dimasukannya variabel bebas tersebut [9].

Koefisen determinasi pada metode MCA dilambangkan sebagai $R^{2}$ yang diperoleh dari rumus berikut.

$$
R^{2}=\frac{E}{T}
$$

Nilai $E$ diperoleh berdasarkan rumus pada Persamaan (7) dan nilai $T$ diperoleh menggunakan rumus pada Persamaan (8).

\section{STUDI KASUS}


Variabel terikat atau variabel yang akan diestimasi pada penelitian ini adalah garis kemiskinan provinsi (GKP), sedangkan upah minimum provinsi (UMP), Rata-Rata Lama Sekolah (RLS), pengeluaran perkapita perbulan (PPP), inflasi(I), produk domestik provinsi bruto (PDRB), dan tingkat pengangguran terbuka (TPT) dianalisis sebagai variabel faktor atau variabel bebas. Jenis data yang digunakan dalam penelitian ini adalah data kuantitatif dan data pada penelitian ini bersumber dari publikasi Badan Pusat Statistika tahun 2017. Secara keseluruhan data yang diamati adalah pada level Provinsi di Indonesia dengan jumlah observasi sebayak 34 Provinsi. Langkah pertama yang dilakukan adalah membuat klasifikasi variabel bebas menjadi kaegori-kategori tertentu kemudian menguji normalitas data.

Tabel 1 Klasifikasi Variabel Dan Uji Normalitas

\begin{tabular}{llr}
\hline Variabel & Kategori & P-Value \\
\hline RLS & $1: 6,48-7,96$ tahun & 0,057 \\
& $2: 7,97-9,44$ tahun & 0,120 \\
& $3: 9,45-10,92$ tahun & 0,200 \\
\hline PPP & $1:$ Pengeluaran kuartil I & 0,200 \\
& $2:$ Pengeluaran kuartil II & 0,200 \\
& $3:$ Pengeluaran kuartil III & 0,200 \\
& $4:$ Pengeluaran kuartil IV & 0,200 \\
\hline PDRB & $1:$ PDRB kuartil I & 0,116 \\
& $2:$ PDRB kuartil II & 0,200 \\
& $3:$ PDRB kuartil III & 0,200 \\
& $4:$ PDRB kuartil IV & 0,200 \\
\hline UMP & $1:$ Rp1.237.700-Rp2.041.133 & 0,200 \\
& $2:$ Rp2.041.133-Rp2.844.566 & 0,200 \\
& $3:$ Rp2.844.566-Rp3.648.000 & 0,200 \\
\hline TPT & 1: Tidak Normal $(\geq 7 \%)$ & 0,192 \\
& $2:$ Normal (<7\%) & 0,200 \\
\hline I & 1 : Di bawah inflasi nasional & 0,200 \\
& $2:$ Di atas inflasi nasional & 0,057 \\
\hline
\end{tabular}

Pada dasarnya klasifikasi variabel bebas menjadi kelas/kelompok tertentu pada Tabel 1 digunakan untuk menyederhanakan data. Sehingga, data lebih mudah untuk dibaca dan dianalisis berdasarkan metode MCA. Dalam pengklasifikasian variabel digunakan konsep tabel distribusi frekuensi, yaitu untuk menentukan jarak antar kategorinya dan menentukan jumlah kategori yang diinginkan. Pada PDRB dan PPP digunakan klasifikasi berdasarkan nilai kuartil data, yang dijelaskan pada bagan berikut.

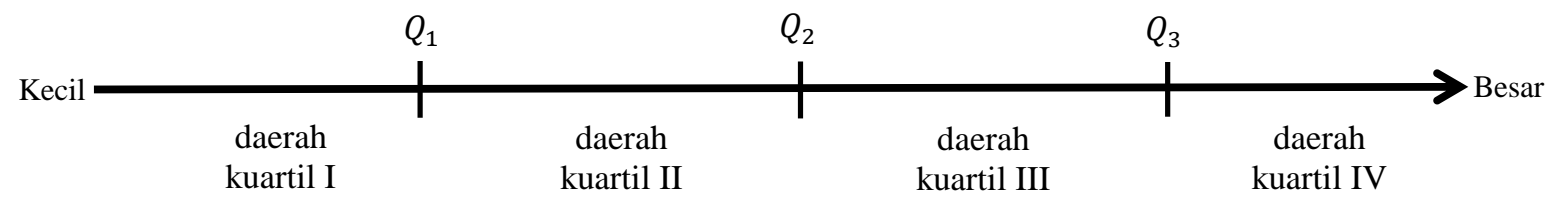

Gambar 1 Klasifikasi Data Variabel PDRB dan PPP

Sedangkan untuk TPT dan Inflasi digunakan standar kualitatif khusus dalam pengklasifikasiannya. TPT diklasifikasikan berdasarkan kenormalan tingkat pengangguran menurut kriteria kenormalan pengangguran dari ILO yaitu 7\% dan variabel inflasi diklasifikan berdasarkan perbandingan antara inflasi provinsi dan inflasi nasional. Tabel 1 juga memuat informasi mengenai uji normalitas menggunakan uji Kolmogorov-smirnov yang menyatakan bahwa masing-masing kategori data yang termuat dalam variabel bebas berdistribusi normal. 
Selanjutnya adalah mengidentifikasi apakah keenam varibel bebas berpengaruh terhadap GKP. Uji yang digunakan adalah uji anova, yaitu dengan menguji perbedaan rata-rata antar kategori yang termuat dalam masing-masing variabel bebas. Dengan hipotesis :

$H_{0}$ : Tidak terdapat perbedaan rata-rata GKP antar kategori dalam variabel

$H_{1}$ : Terdapat perbedaan rata-rata GKP antar kategori dalam variabel

Kriteria pengujian, $H_{0}$ ditolak jika nilai sig. $<0,05$

Hasil Uji Anova ditampilkan dalam Tabel 2 berikut.

Tabel 2 Hasil Uji Anova

\begin{tabular}{lrrrrc}
\hline $\begin{array}{l}\text { Sumber } \\
\text { Keragaman }\end{array}$ & \multicolumn{1}{l}{ Jumlah Kuadrat } & $\begin{array}{c}\text { Derajat } \\
\text { Bebas }\end{array}$ & Rata-rata Kuadrat & F & Sig. \\
\hline RLS & $55.503 .735 .684,984$ & 2 & $27.751 .867 .842,492$ & 8,689 & 0,002 \\
PDRB & $80.025 .575 .476,331$ & 3 & $26.675 .191 .825,444$ & 8,352 & 0,001 \\
PPP & $34.512 .414 .423,576$ & 3 & $11.504 .138 .141,192$ & 3,602 & 0,030 \\
UMP & $3.962 .789 .926,569$ & 2 & $1.981 .394 .963,284$ & 0,620 & 0,547 \\
TPT & $5.574 .099 .516,833$ & 1 & $5.574 .099 .516,833$ & 1,745 & 0,201 \\
I & $2.583 .427 .974,970$ & 1 & $2.583 .427 .974,970$ & 0,809 & 0,379 \\
Galat & $67.070 .244 .905,120$ & 21 & $3.193 .821 .185,958$ & & \\
\hline Total & $249.232 .287 .908,382$ & 33 & $7.552 .493 .572,981$ & & \\
\hline
\end{tabular}

Tabel 2 memberikan informasi bahwa dari keenam variabel bebas yang diamati terdapat tiga variabel yang berpengaruh secara signifikan terhadap GKP, yaitu RLS, PDRB dan PPP karena nilai sig. ketiga variabel tersebut kurang dari 0,05 . Sehingga variabel-variabel bebas yang layak untuk dianalisis menggunakan metode MCA adalah RLS, PDRB dan PPP. Variabel lainnya yang telah dinyatakan tidak signifikan berpengaruh terhadap GKP, dieliminasi dari analisis MCA.

Berikut adalah model hasil analisis menggunakan metode MCA

$$
G K P_{i j k}=\bar{Y}+R L S_{i}+P D R B_{j}+P P P_{k}
$$

Parameter masing-masing kategori disajikan pada Tabel 3 berikut.

Tabel 3 Parameter Model MCA

\begin{tabular}{clr}
\hline Variabel & \multicolumn{1}{c}{ Kategori } & Parameter MCA \\
\hline RLS & $1: 6,48-7,96$ tahun & $-16.729,133$ \\
& $2: 7,97-9,44$ tahun & $-138,606$ \\
& $3: 9,45-10,92$ tahun & $19.495,227$ \\
\hline PDRB & 1 : PDRB kuartil I & $-2.295,915$ \\
& 2 : PDRB kuartil II & $-6.170,259$ \\
& 3 : PDRB kuartil III & $-46.756,136$ \\
& 4 : PDRB kuartil IV & $49.341,600$ \\
\hline PPP & 1 : Pengeluaran kuartil I & $-71.761,086$ \\
& 2 : Pengeluaran kuartil II & $-8.921,519$ \\
& 3 : Pengeluaran kuartil III & $20.986,516$ \\
& 4 : Pengeluaran kuartil IV & $61.036,644$ \\
\hline $\bar{Y}$ (grand mean) & & $429.442,441$ \\
\hline
\end{tabular}

Berdasarkan informasi yang disajikan pada Tabel 3, bahwa semua kategori dalam variabel RLS, PPP dan PDRB memiliki parameter yang berbeda-beda. Hal tersebut juga mengartikan bahwa pengaruh yang diberikan masing-masing kategori terhadap GKP berbeda-beda. Misalnya, pada kategori ke-1 RLS yang memiliki nilai parameter $-16.729,133$ menginterpretasikan bahwa provinsi yang rata-rata 
lama sekolahnya berada pada kategori tersebut memiliki kecenderungan penurunan GKP sebesar Rp16.729. Pada kategori ke-2 RLS, pengaruh yang diberikan terhadap GKP cenderung menurun sebesar Rp138. Sedangkan pengaruh pada kategori ke-3 RLS cenderung meningkatkan GKP sebesar Rp19.495. Apabila ditinjau secara menyeluruh, parameter RLS yang dihasilkan pada kategori ke-1 sampai ke-3 tersebut semakin membesar. Oleh karena itu, RLS memiliki pengaruh yang berbanding lurus terhadap GKP. Begitu pula pada kategori-kategori variabel PPP yang juga memiliki parameter yang unik dan berbanding lurus terhadap GKP. Hal itu nampak pada parameter dari kategori PPP kuartil I sampai kuartil IV yang memiliki pola parameter yang juga semakin membesar. Kemudian untuk kategori PDRB kuartil I menunjukkan bahwa suatu Provinsi yang PDRB-nya berada pada lapisan terbawah maka cenderung GKP-nya turun sebesar Rp2.295. Pada kategori PDRB kuartil II, GKP juga cenderung mengalami penurunan sebesar Rp6.170. Sedangkan parameter pada PDRB kuartil III mengindikasikan penurunan sebesar Rp46.756. Namun pada kategori PDRB kuartil IV justru parameter menunjukkan peningkatkan GKP secara signifikan yaitu sebesar Rp49.341. Berbeda halnya dengan pengaruh RLS dan PPP yang secara menyeluruh berbanding lurus terhadap GKP, pengaruh PDRB tidak dapat disimpulkan secara menyeluruh karena parameter pada PDRB kuartil I sampai kuartil III berpola menurun, sedangkan pada kuartil IV polanya terhenti dan justru mengalami peningkatan. Sehingga tidak ditemukan pola yang spesifik pada parameter-parameter kategori variabel PDRB.

Prosedur selanjutnya adalah uji simultan model, yaitu untuk memperoleh kepastian bahwa model MCA yang meliputi variabel RLS, PPP dan PDRB secara umum signifikan dalam mengestimasi GKP. Pengujian dilakukan melalui prosedur sebagai berikut:

Hipotesis:

$H_{0}: a_{i}=b_{j}=c_{k}$ (tidak ada perbedaan parameter kategori antar variabel)

$H_{1}: a_{i}, b_{j}, c_{k} \neq 0$ (minimal ada satu parameter kategori tidak sama dengan nol)

Kriteria pengujian, $H_{0}$ ditolak jika nilai sig. Tabel $F<0,05$

Tabel 4 Uji Simultan Model GKP

\begin{tabular}{crcrc}
\hline Uji & \multicolumn{4}{c}{ Nilai F } \\
\cline { 2 - 5 } Simultan & Statistik & $(C-P)$ & $(N-C+P-1)$ & Sig. \\
\cline { 2 - 5 } Model & 6,710 & 8 & 25 & 0,000106
\end{tabular}

Berdasarkan Tabel 4 diketahui bahwa sig. kurang dari 0,05. Oleh karena itu, dapat disimpulkan bahwa $H_{0}$ ditolak, atau dengan kata lain model MCA yang terbentuk memang benar secara umum dapat mengestimasi GKP.

Model GKP yang dinyatakan signifikan, juga memiliki nilai koefisien determinasi $\left(R^{2}\right)$ yang baik yaitu $68,2 \%$. Selain itu, pada Tabel 5 berikut diperoleh juga tingkat keeratan variabel bebas terhadap GKP berdasarkan nilai Eta dan Beta.

Tabel 5 Statistik Eta dan Beta

\begin{tabular}{lrr}
\hline Variabel & Statistik Eta & Statistik Beta \\
\hline RLS & 0,472 & 0,140 \\
PDRB & 0,657 & 0,399 \\
PPP & 0,719 & 0,581 \\
\hline
\end{tabular}

Nilai-nilai tersebut memperlihatkan besarnya proporsi keeratan pengaruh variabel bebas terhadap GKP. Untuk nilai eta, memberikan informasi keeratan hubungan variabel bebas terhadap GKP sebelum dikontrol oleh variabel bebas lain. Seperti PPP pada Tabel 5 memiliki nilai eta 0,719 , artinya besar pengaruh PPP terhadap GKP apabila hanya berdiri sendiri tanpa ada keterlibatan variabel bebas lain adalah sebesar 71,9\%. Sedangkan Beta menunjukan besarnya keeratan pengaruh variabel bebas 
terhadap GKP setelah dikontrol oleh variabel bebas lain. Dalam hal ini PPP yang memiliki nilai beta sebesar 0,581 memberikan pengaruh terhadap GKP sebesar 58,1\% setelah dilibatkan variabel lain. Begitu pula untuk variabel RLS dan PDRB. Berikut hasil estimasi GKP dari 34 Provinsi yang ada di Indonesia melalui pendekatan metode MCA.

Tabel 5 Estimasi Nilai GKP

\begin{tabular}{|c|c|c|c|c|c|c|c|}
\hline $\mathrm{NO}$ & Provinsi & GKP & $i$ & $J$ & $k$ & $G K P_{i j k}$ & Absolute Percentage Error \\
\hline 1 & Aceh & 467.242 & 2 & 2 & 2 & $414.212,056$ & 11,350 \\
\hline 2 & Sumatera Utara & 435.492 & 3 & 4 & 3 & $519.265,784$ & 19,237 \\
\hline 3 & Sumatera Barat & 466.430 & 2 & 3 & 3 & $403.534,215$ & 13,485 \\
\hline 4 & Riau & 478.445 & 2 & 4 & 4 & $539.682,079$ & 12,799 \\
\hline 5 & Jambi & 401.765 & 2 & 1 & 3 & $447.994,436$ & 11,507 \\
\hline 6 & Sumatera Selatan & 379.052 & 2 & 2 & 2 & $414.212,056$ & 9,276 \\
\hline 7 & Bengkulu & 474.010 & 2 & 1 & 3 & $447.994,436$ & 5,488 \\
\hline 8 & Lampung & 392.201 & 2 & 1 & 2 & $418.086,401$ & 6,600 \\
\hline 9 & Kep. Bangka Belitung & 672.104 & 2 & 4 & 4 & $539.682,079$ & 19,703 \\
\hline 10 & Kepulauan Riau & 543.187 & 3 & 4 & 4 & $559.315,912$ & 2,969 \\
\hline 11 & DKI Jakarta & 520.690 & 3 & 4 & 4 & $559.315,912$ & 7,418 \\
\hline 12 & Jawa Barat & 367.805 & 2 & 3 & 2 & $373.626,180$ & 1,583 \\
\hline 13 & Jawa Tengah & 355.306 & 1 & 2 & 1 & $334.781,962$ & 5,776 \\
\hline 14 & DI Yogyakarta & 369.606 & 3 & 2 & 2 & $433.845,890$ & 17,381 \\
\hline 15 & Jawa Timur & 368.793 & 1 & 4 & 1 & $390.293,821$ & 5,830 \\
\hline 16 & Banten & 405.965 & 2 & 3 & 2 & $373.626,180$ & 7,966 \\
\hline 17 & Bali & 376.733 & 2 & 3 & 4 & $443.584,343$ & 17,745 \\
\hline 18 & Nusa Tenggara Barat & 363.755 & 1 & 1 & 1 & $338.656,307$ & 6,900 \\
\hline 19 & Nusa Tenggara Timur & 342.303 & 1 & 1 & 1 & $338.656,307$ & 1,065 \\
\hline 20 & Kalimantan Barat & 413.806 & 1 & 2 & 3 & $427.529,565$ & 3,316 \\
\hline 21 & Kalimantan Tengah & 440.649 & 2 & 3 & 4 & $443.584,343$ & 0,666 \\
\hline 22 & Kalimantan Selatan & 424.670 & 2 & 3 & 4 & $443.584,343$ & 4,454 \\
\hline 23 & Kalimantan Timur & 589.588 & 3 & 4 & 4 & $559.315,912$ & 5,134 \\
\hline 24 & Kalimantan Utara & 581.681 & 2 & 4 & 4 & $539.682,079$ & 7,220 \\
\hline 25 & Sulawesi Utara & 360.907 & 2 & 3 & 3 & $403.534,215$ & 11,811 \\
\hline 26 & Sulawesi Tengah & 418.035 & 2 & 2 & 2 & $414.212,056$ & 0,915 \\
\hline 27 & Sulawesi Selatan & 306.250 & 2 & 2 & 1 & $351.372,489$ & 14,734 \\
\hline 28 & Sulawesi Tenggara & 311.592 & 2 & 1 & 1 & $355.246,833$ & 14,010 \\
\hline 29 & Gorontalo & 323.133 & 1 & 1 & 1 & $338.656,307$ & 4,804 \\
\hline 30 & Sulawesi Barat & 323.561 & 1 & 1 & 1 & $338.656,307$ & 4,665 \\
\hline 31 & Maluku & 466.508 & 3 & 1 & 1 & $374.880,667$ & 19,641 \\
\hline 32 & Maluku Utara & 415.541 & 2 & 3 & 2 & $373.626,180$ & 10,087 \\
\hline 33 & Papua Barat & 544.623 & 3 & 2 & 3 & $463.753,925$ & 14,849 \\
\hline \multirow[t]{2}{*}{34} & Papua & 499.615 & 1 & 4 & 3 & $483.041,424$ & 3,317 \\
\hline & & & & & & MAPE & 8,932 \\
\hline
\end{tabular}

Berdasarkan hasil perhitungan rata-rata persentase kesalahan pada 34 provinsi diperoleh nilai MAPE sebesar $8,932 \%$. Nilai tersebut cukup membuktikan bahwa model sangat baik untuk mengestimasi nilai GKP, karena indikator sebuah model dikatakan sangat baik adalah nilai MAPE yang lebih kecil dari $10 \%$ [7] 


\section{KESIMPULAN}

MCA pada penelitian ini berhasil mengidentifikasi faktor yang berpengaruh terhadap penentuan GKP. Hasil yang diperoleh bahwa variabel RLS, PPP dan PDRB berpengaruh signifikan terhadap GKP. Model yang dihasilkan yaitu sebagai berikut.

$$
G K P_{i j k}=429.442,441+R L S_{i}+P D R B_{j}+P P P_{k}
$$

Parameter yang bersesuaian terhadap kategori masing-masing variabel disajikan pada Tabel 3.

Berdasarkan statistik beta, PPP menjadi faktor terbesar yang berpengaruh terhadap GKP, yaitu dengan proporsi $58,1 \%$. PDRB menempati urutan kedua yaitu dengan pengaruh sebesar 39,9\%. Sedangkan RLS adalah faktor yang pengaruhnya terkecil yaitu dengan proporsi pengaruh $14,0 \%$. Model MCA yang diperoleh juga memberikan hasil yang sangat baik, hal ini dibuktikan dengan nilai MAPE sebesar 8,932\%.

\section{DAFTAR PUSTAKA}

[1] Badan Pusat Statistika. Perhitungan dan Analisis Kemiskinan Makro Indonesia. Jakarta: BPS; 2017

[2] Saleh S. Faktor-Faktor Penentu Tingkat Kemiskinan Regional Di Indonesia, Jurnal Ekonomi Pembangunan, 2002; Vol 2:87-102.

[3] Andrew F, Morgan JN, Sonquist JA, Klem L. Multiple Classification Analysis. A report on a computer program for multiple regession using categorical predictors, Second Edition. Michigan: The Univerity of Michigan; 1973.

[4] Kusnandar D. Metode Statistik dan Aplikasinya dengan Minitab dan Excel. Yogyakarta: Madyan Press; 2004.

[5] Siegel S. Nonparametric Statistics For The Behavioral Sciences, New York: The Mc Graw-Hill Companies; 1956.

[6] Suharjo B. Statistika Terapan Disertai Contoh Aplikasi dengan SPSS. Yogyakarta: Penerbit Graha Ilmu; 2013.

[7] Pakaja F, Naba A, Purwanto. Peramalan Penjualan Mobil Menggunakan Jaringan Syaraf Tiruan dan Certainty Factor, Jurnal EECCIS, 2012; 6: 23-28.

[8] Susel A. Multiple Classification Analysis. Theory and Aplication To Demography, Folia Economica, 2011; 255: 183-189.

[9] Fauzy A. Statistik Industri. Jakarta: Penerbit Erlangga, 2008.

$\begin{array}{ll}\text { ALVIN FIRDAUS } & \begin{array}{l}\text { : Jurusan Matematika FMIPA UNTAN, Pontianak } \\ \text { alvinfirdaus0707@ student.untan.ac.id }\end{array} \\ \text { SHANTIKA MARTHA } & \begin{array}{l}\text { Jurusan Matematika FMIPA UNTAN, Pontianak } \\ \text { shantika.martha@ math.untan.ac.id }\end{array} \\ \text { NURFITRI IMRO’AH } & \begin{array}{l}\text { Jurusan Matematika FMIPA UNTAN, Pontianak } \\ \text { nurfitriimroah@math.untan.ac.id }\end{array}\end{array}$

